\title{
Biochemical and Haematological Effects and Histopathological Changes caused by Moringa oleifera on Albino Rats
}

\author{
ELmuaiz Gasmalbari ${ }^{1}$, Hatil H. EL-Kamali ${ }^{2}$, Osama S. Abbadi*3 \\ 1 Department of biochemistry, Orotta College of Medicine and Health Sciences, Asmara, Eritrea. \\ 2 Department of Biotechnology, Faculty of Science and Technology, Omdurman Islamic University, Sudan. \\ 3 Department of Biochemistry, Faculty of Medicine, Omdurman Islamic University, Sudan. \\ *Corresponding Author: Osama S. Abbadi, Department of Biochemistry, Faculty of Medicine, Omdurman Islamic University, \\ Sudan, E-mail: aslikhalis@yahoo.com
}

\begin{abstract}
Background: Of the plant family Moringaceae, Moringa oleifera is the most popular. It draws researchers' attention by its nutritional and phytochemical properties. The potential effects of this plant are still to be explored. This study aimed to evaluate the effect of Moringa olifiera in the blood glucose, serum lipids, hemoglobin, hematologic values of blood cells, and the possible organ toxicity of this plant by measuring liver and kidney functions and histology. Materials and method: Moringa olifiera leaves were pounded to powder using a pestle. 100mg for each kilogram of bodyweight $(\mathrm{mg} / \mathrm{kg} / \mathrm{bw})$ were weighted for each rat. Sera for blood glucose, lipid profile, blood parameters, and histology slides for liver and kidneys were prepared and studied after the above dose administration-orally, for three weeks. Results: Administration of aqueous Moringa leaves $100 \mathrm{mg} / \mathrm{kg} / \mathrm{bw}$ to rats for 21 days caused a significant decrease in the triglycerides level, plasma cholesterol, blood glucose, platelets count, plasma proteins and albumin. There was a significant increase in the body weight. White blood cells (WBCs) and packed cell volume (PCV) increased significantly, but the changes in Red blood cells (RBCs), haemoglobin level, blood urea and creatinine were not statistically significant. Features of tissue injury were seen in the liver and renal histology slides. Conclusion: The effects of Moringa olifiera in albino rats in this study agrees with most of the previous researches, but contradicts the literature with regards to the cholesterol and renal function results.
\end{abstract}

Keywords: Moringa oleifera, Lipid profile, Bodyweight, Renal function, Hematology.

\section{INTRODUCTION}

The most planted species of genus Moringa is Moringa oleifera, which is also known as Moringa pterygosperma. In fact, the family Moringaceae has only the genus Moringa. This plant species is characterized by a good adaptation to dehydration, a rapid growth pattern, and a wide range of geographical spread. Common English names for Moringa oleifera include horseradish tree; drumstick tree; and benzoil tree [1]. When harvested, these trees are re-sized every year to the height between one to two meters to facilitate future leaves and pods collection1. The immature seed pods, called "drumsticks", are excellent provenances for potassium, magnesium, dietary fiber, and manganese ${ }^{[2]}$. The mature seeds contain good bulk of water soluble B vitamins, minerals, and characteristically raised amount of vitamin C. Moringa seed oil also has potential for use as bio-fuel [3]. A popular benefit of Moringa trees is fighting malnutrition, both in newborns and their breastfeeding mothers. The nutritional potentials of Moringa were accredited by many specialized health and development non- governmental organizations; Educational Concerns for Hunger Organization (ECHO), Volunteer Partnerships for West Africa (VPWA), as well as BBC world service multilingual broadcast, all designated Moringa as the natural nutrition for the tropics2. As mentioned in the WHO 1994 report, doubtfulness about Moringa nutritional potentials is of past, and its consumption in starvation is now practiced as a rule of a thumb imminent ${ }^{[4]}$. This plant is richer than milk in calcium, stores more dietary iron than spinach, and outweighs carrots in ßeta carotene content ${ }^{[5]}$. Other than the nutritional value of Moringa, chemical properties of its ingredients had been researched with regards to its bacterial infection resistance ${ }^{[6]}$, combating diabetes in rats ${ }^{[7]}$, antiviral role (particularly in Epstein-Barr virus infection) ${ }^{[8]}$, and treatment of skin papilloma8. Moringa has been used in folk medicine to control blood pressure and glucose levels ${ }^{[9]}$. Locals in some 
African and Asian countries believe that moringa can increase breast milk production in lactating mothers. Moringa preparation has been reported to have an antispasmodic, hypocholesterolemic, hypoglycemic, hypotensive, ulcer relieving roles. It also had been used for combating the cercaria stage of Schistosomiasis.

Also, Moringa was used as an anti-microbial agent. It is well known for its pharmacological action too and is used for the traditional treatment of diabetes mellitus [10], hepatotoxicity, Rheumatism, venomous bites, and also for cardiac stimulation [11]. Grinded Moringa seeds were tested for their ability to purify water; they proved to be efficient in pollution reduction and decreasing bacterial load in river water ${ }^{[12]}$.

The potential effects of the Moringa are still to be explored. This study aimed to evaluate the effect of Moringa olifiera in the blood glucose, serum lipids, hemoglobin, hematologic values of blood cells, and the possible organ toxicity of this plant by measuring liver and kidney functions and histology.

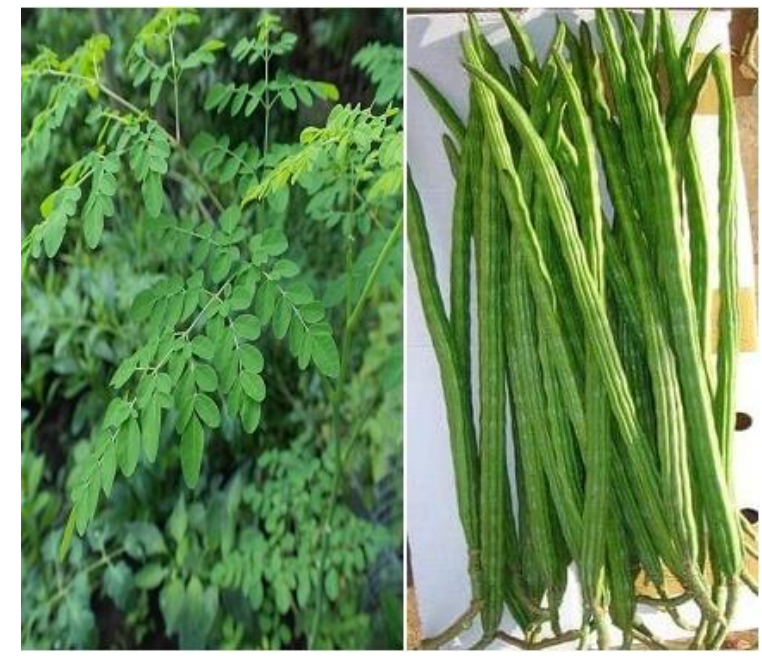

Figure 1: Shows Moringa oleifera leaves (left), and pods (right).

\section{MATERIALS AND METHODS}

\section{i. Plant collection}

Moringa oleifera leaves were harvested in Sudan. Leaves were bought from the Omdurman market. They were pounded to powder using a pestle. 100mg for each kilogram of body weight $(\mathrm{mg} / \mathrm{kg} / \mathrm{bw})$ were weighted for each rat.

\section{ii. Animals}

The animals used in the study were 24 albino Rat males (90$125 \mathrm{~g}$ ), they were maintained in an experimental animal house at aromatic plants research institute (MAPRI), Khartoum Sudan. They were preserved in cages and fed on diet special for rats; at the start of the experiment all the animals were weighed.

\section{iii. Preparation of the extract}

10 grams of each powdered plant sample was refluxed with 100 $\mathrm{ml}$ of $80 \%$ of ethanol four 4 hours. The cooled solution was filtered and enough $80 \%$ ethanol was passed through the volume of the filtrate to $100 \mathrm{ml}$. The preparation was then used in the different tests of this research.
Periodical blood samples were collected by cervical decapitation from diethyl ether anesthetized rats into heparinized bottles for hematological studies. Blood samples collected in clean Nonheparinized bottles were allowed to clot.

\section{v. Histopathology}

The liver and kidney of all rats were fixed to preserve tissues for degradation and to maintain the structure of organelles, in buffered formalin in labeled bottles. Tissues were processed routine and water removed from tissues after dehydrated and cleared. Tissues were then filtered with embedding in paraffin wax. Sections of $5 \mu$ thicknesses were cut with a microtome. Hematoxylin and eosin (H\&E stains) were used as the stain method. Slides were examined under the light microscope and Photomicrographs were taken in Khartoum hospital.

\section{vi. Hematology}

Lewis (1991) manual Methods were followed to determine Red blood cells count (RBCs), the White blood cells count (WBCs), Packed cell volume (PCV \%), Red cell distribution (RDW), Hemoglobin concentration (Hb\%), Mean corpuscular volume (MCV), Mean corpuscular hemoglobin concentration (MCHC), and Mean corpuscular hemoglobin $(\mathrm{MCH})$.

\section{vii. Sero- biochemical analysis: The tests involved were}

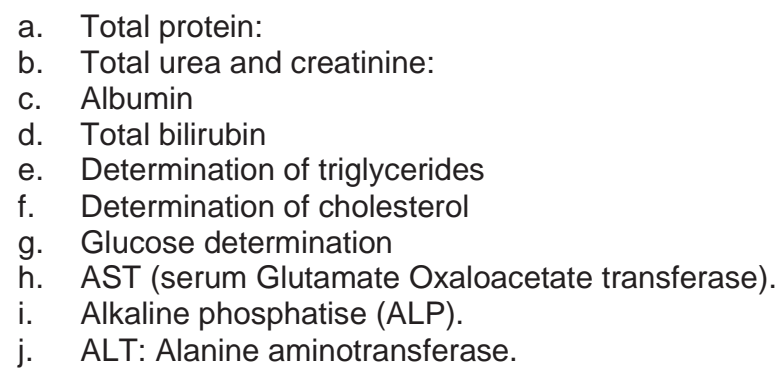

\section{viii. Statistical analysis}

Results were blotted in table containing different investigations performed, values in test and controls, and the respective Pvalue. Histological changes were remarked by comparing the test and control samples. The data were subjected to one -way analysis of variance (ANOVA), assuming equal variances, and results were considered to be significant at $P<0.05$.

\section{RESULTS}

The effect of Moringa on lipid profile (Cholesterol and Triglycerides):

Administration of aqueous Moringa leaves $100 \mathrm{mg} / \mathrm{kg} / \mathrm{bw}$ to rats for 21 days caused an obvious alteration in the triglycerides level and plasma cholesterol compared to control. This reduction was found to be significant $(P<0.05)$.

The effect of Moringa leaves on the plasma glucose: There was a significant reduction in random blood glucose.

The effect of Moringa oliefera leaves on body weight: Administration of aqueous Moringa leaves caused a significant (but not high) gain in weight at $(\mathrm{p}<0.05)$ when compared to the control group which gained weight.

\section{iv. Collection of blood and serum samples and plasma}


Effect of Moringa on plasma protein and albumin: Moringa caused a significant reduction in protein and plasma albumin.

The effect of Moringa leaves on liver enzymes: Administration of aqueous Moringa leaves $100 \mathrm{mg} / \mathrm{kg} / \mathrm{bw}$ to rats for 21 days caused a significant decrease in $(A L T)$ at $(p<0.05)$. ALP and AST were normal.

Effect of Moringa oliefera leaves on liver histology: Administration of aqueous Moringa leaves for 21days were showed sinusoidal dilation with tiny cytoplasmic vacillations and patches of parenchymal necrosis.

Effect of Moringa oliefera leaves on hematology: Administration of aqueous Moringa leaves on rats for 21days caused a significant decrease in the platelets count, an insignificant reduction on RBCs and hemoglobin, while WBCs increased significantly.

The effect of Moringa leaves on plasma creatinine and blood urea: there were no alterations in creatinine level and blood urea compared to controls.

The effect of Moringa leaves on renal histology: Some hemorrhagic patches were noticed.

Table 1: List of the results of Moringa olifiera administration to albino rats for 21 days.

\begin{tabular}{|c|c|c|c|}
\hline Test & $\begin{array}{l}\text { Value before } \\
\text { Moringa } \\
\text { (control) }\end{array}$ & $\begin{array}{l}\text { Value after } \\
\text { Moringa } \\
\text { (test) }\end{array}$ & $\begin{array}{l}\text { P-value } \\
\text { of the } \\
\text { difference. }\end{array}$ \\
\hline $\begin{array}{l}\text { Triacylglycerols } \\
(\mathrm{mg} / \mathrm{dl})\end{array}$ & $82.8 \pm 0.9$ & $70.14 \pm 0.81$ & $\leq 0.05$ \\
\hline Cholesterol (mg/dl). & $55 \pm 0.76$ & $31.60 \pm 0.82$ & $\leq 0.05$ \\
\hline Blood sugar (mg/dl) & $74 \pm 1.1$ & $63.86 \pm 0.93$ & $\leq 0.05$ \\
\hline Body Weight (gm) & $97.2 \pm 0.6$ & $98.1 \pm 0.71$ & $\leq 0.05$ \\
\hline AST (iu) & $135 \pm 11.6$ & $0.150 \pm 0.05$ & $>0.05$ \\
\hline ALT (iu) & $42 \pm 7.12$ & $19.05 \pm 4.76$ & $\leq 0.05$ \\
\hline ALP (iu) & $152.5 \pm 5.9$ & $159.8 \pm 6.44$ & $>0.05$ \\
\hline Protein $(\mathrm{g} / \mathrm{dl})$ & $7.2 \pm 0.54$ & $6.067 \pm 0.30$ & $\leq 0.05$ \\
\hline ALB (g/dl) & $4.2 \pm 0.4$ & $3.233 \pm 0.26$ & $\leq 0.05$ \\
\hline Bilirbin (mg/ dl) & $0.1 \pm 0.02$ & $0.150 \pm 0.05$ & $>0.05$ \\
\hline RBC $\left(\times 10^{6} \mathrm{~mm}^{3}\right)$ & $6.0 \pm 0.77$ & $5.037 \pm 0.52$ & $>0.05$ \\
\hline $\mathrm{MCV}\left(\right.$ micro $\left.\mathrm{m}^{3}\right)$ & $55 \pm 10.6$ & $44.17 \pm 9.84$ & $\geq 0.05$ \\
\hline $\mathrm{MCH}(\mathrm{pg})$ & $21 \pm 0.4$ & $20.47 \pm 0.4$ & $>0.05$ \\
\hline $\mathrm{MCHC}(\%)$ & $33.0 \pm 1.1$ & $34.98 \pm 1.23$ & $>0.05$ \\
\hline WBC $\left(\times 10^{6} \mathrm{~mm} 3\right)$ & $9.3 \pm 0.8$ & $10.41 \pm 0.8$ & $\leq 0.05$ \\
\hline RDWSD (\%) & $30 \pm 7.5$ & $36.38 \pm 8.33$ & $>0.05$ \\
\hline HGB (g/dl) & $13.0 \pm 1.1$ & $11.49 \pm 0.92$ & $>0.05$ \\
\hline PLT $\left(10^{3} / \mathrm{ml}\right)$ & $275 \pm 16.1$ & $32.10 \pm 4.78$ & $\leq 0.05$ \\
\hline PCV (\%) & $41.8 \pm 0.7$ & $51.81 \pm 0.90$ & $\leq 0.05$ \\
\hline Urea (mg /dl) & $30 \pm 4.3$ & $26.00 \pm 3.54$ & $>0.05$ \\
\hline Creatinine (mg/ dl) & $1.0 \pm 0.5$ & $0.900 \pm 0.41$ & $>0.05$ \\
\hline
\end{tabular}

www.cjmronline.com | Chinese Journal of Medical Research | July- September 2020

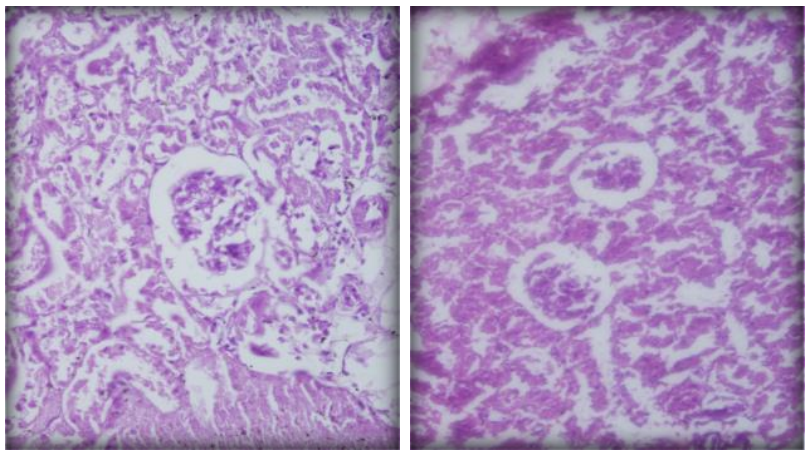

Figure 2: Photomicrograph section through the kidney of an albino rat; the left slide is a control, the right side is a kidney treated with Moringa olifiera. The test contains areas of hemorrhage.
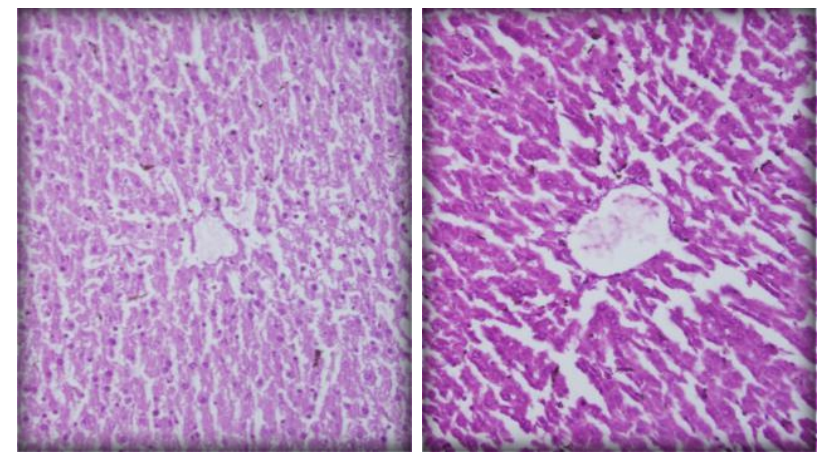

Figure 3: A section through the livers of an albino rat; the left slide is a control; the right side is a liver of rat fed in Moringa olifiera for three weeks. The test contains areas of hemorrhage. a dilated sinusoid seen in the middle. Cell necrosis is also detected.

\section{DISCUSSION}

This research was performed to measure the effects of alcohol extract Moringa olifiera in the biochemical, histological, and hematological parameters of Laboratory Rats. Administration of aqueous Moringa leaves $100 \mathrm{mg} / \mathrm{kg} / \mathrm{bw}$ orally to laboratory rats for 21 days caused an obvious reduction in the triglycerides level, compared to control. This reduction was found to be significant $(\mathrm{P}<0.05)$. This result agreed with Ghasi et al. study (2000) which concluded that reduction of triglyceride is predictable after the ingestion of Moringa leaves [13]. Moringa leaves extract ingestion also caused a reduction in plasma cholesterol. This result is in contrast to the Ghasi report ${ }^{17}$. The decrease in cholesterol may be due to the resorption of the non-dietary cholesterol ${ }^{[14]}$, or an increase in the rate of secretion into the intestinal tract. The changes in the lipid profile with Moringa treatment could decrease the incidence of atherosclerosis. Moringa leaves contain sterols, and Sitosterol may reduce cholesterol [15]. Another possible explanation of the Cholesterol level decrease is the doubled effect of increased fecal excretion (in the form of steroids) and decreased endogenous cholesterol uptake. Moringa activates the enzyme lipoprotein lipase which induces uptake of cholesterol from blood vessels, it also enhances the activity of the enzyme lecithin cholesterol acyltransferase in $\mathrm{HDL}$, which has a role in scavenging of cholesterol ${ }^{[16]}$.

Coumarin, a compound abundant in Moringa, was found to decrease the plasma Triacylglycerol (TAG) by $55 \%$ and total cholesterol (TC) by $2 \%$, and also increases the HDL /TG ratio by $42 \%{ }^{[17]}$. Polyphenols can inhibit fat digestion by lipase (in vitro) resulting in decreased lipolysis of Triacylglycerol. Polyphenols also inhibit pancreatic lipase and triacylglycerol absorption, inhibit apoprotein $\beta$ synthesis in intestine mucosa, cholesterol esterification, and intestinal lipoprotein production ${ }^{[18]}$. 
Administration of aqueous Moringa leaves $100 \mathrm{mg} / \mathrm{kg} / \mathrm{bw}$ to rats for 21days caused an obvious reduction in random blood glucose level compared to control. These results are in agreement with the researches of Bhishagratna [19] and Kar et al. [20]. Insulin deficiency, either due to decreased production or increased insulin antagonization by other hormones, can leads to diabetes and eventually diabetic complications [21].

WHO is always spotting the light on the rational use of traditional and natural herbal plants for the treatment of diabetes mellitus [22]. It is likely to expect that aqueous extract of Moringa increases the tissues utilization of glucose in muscle and adipose ${ }^{[23,24]}$ and by inhibiting hepatic gluconeogenesis and absorption of glucose into muscle and adipose tissues [25]. Nbenzyl-thio-carbamates were isolated from methanol extract of dried Moringa leaves significantly stimulated insulin release from the pancreas [26]

Moringa leaves caused a significant loss in weight in this current study as compared to control. Moringa extract may inhibit the pancreatic lipase or enhance hormone-sensitive lipase to breakdown triacylglycerols or inhibit endogenous triacylglycerol defection. Usually, TAG is found in the VLDL that carries endogenous TAG to adipocytes and lead to gain weight. Flavonoids, which are abundant in Moringa, act as thermogenic compounds and it may accelerate our body's ability to burn fat as fuel ${ }^{[27]}$.

In this study, Moringa caused a significant reduction in albumin. Albumin in urine both detect the glomerular disease and estimates its severity. A decrease in albumin and protein may be due to some ingredients in Moringa leaves. Moringa contains iso-thiocyanate which produces glycosides; a toxin that could reduce total protein ${ }^{[28]}$.

There was also a significant decrease in (ALT) while ALP and AST were normal. This excludes the toxicity effect of Moringa on the liver, despite ALT reduction and detected liver damage [29]. Histology slides showed sinusoidal dilation with a tiny cytoplasmic vacillation, and tissues appeared normal with minimal liver parenchymal necrosis. This necrosis may be due to a secondary metabolite represented in Moringa, such as isothiocyanate which produces glycosides that leads to necrosis. The anti-oxidants in Moringa may have combated this glycosides-induced damage ${ }^{[30]}$.

Moringa caused a reduction in RBCs and hemoglobin but it wasn't significant. Moringa may affect bone marrow synthesis of enough erythrocytes. PCV was increased significantly; plasma trapping is increased in macrocytic anemia [31], so may be Moringa has some compounds which prevent plasma trapping. Moringa leaves are very rich with iron, and probably for this reason RDW was normal [32]. WBCs were increased significantly. WBCs play an important role in the defense line and operate as phagocytes against invading microorganisms. Change and damage to liver histology may have caused elevation in WBCs. Secondary compounds in Moringa represented to the immune system as antigens- may be the reason for this elevation of WBCs.

In contrast to Atessahin et al. research of 2003, Administration of aqueous Moringa leaves to rats caused no alteration in creatinine level and blood urea compared to controls ${ }^{[33]}$. There were no changes in renal histology, and the detected hemorrhagic patches are probably traumatic. This result is in agreement with the 2007 research of Martinez et al. ${ }^{[34]}$. Other reports showed that the administration of Moringa oleifera to nephrotoxic rabbits caused a significant lowering of creatinine and blood urea after elevation [35, 36]. Moringa does not only protect the renal tissue; it simultaneously increases its repair and regeneration potentials. This may be attributed to the antioxidant effect of polyphenols in Moringa. The anti-oxidation may be achieved by free radical's neutralization or metal chelation ${ }^{37,38]}$.

\section{CONCLUSIONS}

This was an experimental study on albino rats to determine the effects of oral administration of Moringa olifiera leaves extract for three weeks in a dose of $100 \mathrm{mg} / \mathrm{kg} / \mathrm{bw}$. It had been found that Moringa caused weight gain and increase in WBCs count and Packed cell volume. The extract had led to the reduction of blood glucose, serum Cholesterol, triglycerides, and proteins. There was no significant effect on the renal profile. Some damage occurred to the renal and hepatic tissues.

\section{Conflict of interest}

None of the authors have a conflict of interest to report with regard to this research.

\section{Authors contributions}

Elmuiz gasmalbari: Design and concept of the study, performing practical procedures, and writing the script. Hatil El-Kamali: Supervision, editing, and approving the final manuscript.

Osama Abbadi: Statistical analysis, writing and revision of the manuscript.

\section{REFERENCES}

1. Bhaumik A, Kumar PS, Chopra M. Evaluation of Hepatoprotective and antipyretic activity of Ethanolic extract of root of Moringa oleifera lam. World J Pharmaceut Res. 2016; 5(9):1112-1122. DOI: 10.20959/wjpr20169-6939.

2. Fuglie LJ. The Miracle Tree: Moringa oleifera: Natural Nutrition for the Tropics. Church World Service. Dakar (Sen); 1999; pp. 68.

3. Rashid U, Anwar F, Moser BR, Knothe G. Moringa oleifera oil: a possible source of biodiesel. Bioresour Technol. 2008; 99(17):8175-9. doi:10.1016/j.biortech.2008.03.066.

4. WHO Publications, 1994. Prevention of Diabetes Mellitus: Report of a WHO study group. Technical Report Series No.844, world Health Organization, Geneva, Switzerland, PP. 78. URL: https://apps.who.int/iris/bitstream/handle/10665/39374/WHO_TR S_844.pdf?sequence $=1$ \&isAllowed $=y$

5. Sanchez MDI, Lopez CJ, Vazquez NJR. High -performance liquid chromatography method to measure and $\beta$-tocopherol in leaves, flowers and fresh beans from Moringa oleifera. J Chromatogr A. 2006; 1105: 111-114. https://doi.org/10.1016/ j.chroma.2005.07.048

6. Peixoto JR, Silva GC, Costa RA, de Sousa Fontenelle JR, Vieira $\mathrm{GH}$, Filho $A A$, dos Fernandes Vieira RH. In vitro antibacterial effect of aqueous and ethanolic Moringa leaf extracts. Asian Pac J Trop Med. 2011; 4(3):201-4. doi: 10.1016/S19957645(11)60069-2.

7. Ndong M, Uehara M, Katsumata S, Suzuki K. Effects of Oral Administration of Moringa oleifera Lam on Glucose Tolerance in Goto-Kakizaki and Wistar Rats. J Clin Biochem Nutr. 2007; 40(3):229-33. doi: 10.3164/jcbn.40.229.

8. Bharali R, Tabassum J, Azad MR. Chemomodulatory effect of Moringa oleifera, Lam, on hepatic carcinogen metabolising enzymes, antioxidant parameters and skin papillomagenesis in mice. Asian Pac J Cancer Prev. 2003; 4(2):131-9.URL: https://pubmed.ncbi.nlm.nih.gov/12875626/

9. Bidwe A, Khan TN. Effect of drumstick (moringa oliefera) leaves powder chutney on blood pressure. Int J Food Nutr Sci. 2013; 2(3): 95-98. URL: http://www. ijfans.org/article.asp?issn=23191775; year $=2013$; volume $=2$;issue $=3$; spage $=95$; epage $=98$; aulast $=$ Bidwe;type $=0$

10. Bhishagratna KK. An English Translation of Sushrutam Samhita based on the Original Sanskrit Text. Vol. 3, Chowkhamba Sanskrit Series Office, Varanasi, India; 1991: pp: 213-219.

11. Chaudhary RD, Chopra RD. Herbal Drug Industry: A Practical 
Approach to Industrial pharmacognosy, Eastern publishers, New Delhi: 1996: pp58.

12. Lea M. Bioremediation of turbid surface water using seed extract from Moringa oleifera Lam. (drumstick) tree. Curr Protoc Microbiol. 2010; Chapter 1:Unit1G.2. doi:10.1002/9780471729259. mc01g02s16.

13. Ghasi S, Nwobodo E, Ofili JO. Hypocholesterolemic effects of crude extract of leaf of Moringa oleifera Lam in high-fat diet fed Wister rats. J Ethnopharmacol. 2000; 69(1): 21-25. doi: 10.1016/s0378-8741(99)00106-3.

14. Lecerf JM, de Lorgeril M. Dietary cholesterol: from physiology to cardiovascular risk. $\mathrm{Br} J$ Nutr. 2011; 106(1):6-14. doi: 10.1017/S0007114511000237.

15. Verma AR, Vijayakumar M, Mathela CS, Rao CV. In vitro and in vivo antioxidant properties of different fractions of Moringa oleifera leaves. Food Chem Toxicol. 2009; 47(9):2196-2201. doi 10.1016/.j.fct.2009.06.005.

16. Olson RE. Discovery of the lipoproteins, their role in fat transport and their significance as risk factors. J Nutr. 1998; 128(2 Suppl):439S-443S. doi: 10.1093/jn/128.2.439S .

17. Nadeem M, Imran M. Promising features of Moringa oleifera oil: recent updates and perspectives. Lipids Health Dis. 2016; 15: 212. doi: 10.1186/s12944-016-0379-0

18. Sugiyama H, Akazome Y, Shoji T, Yamaguchi A, Yasue M, Kanda $\mathrm{T}$, Ohtake Y. Oligomeric procyanidins in apple polyphenol are main active components for inhibition of pancreatic lipase and triglyceride absorption. J Agric Food Chem. 2007; 55(11):4604-9. doi: 10.1021/jf070569k. Erratum in: J Agric Food Chem. 2007 Ju 11; 55(14):5906.

19. Bhishagratna, KK. An English translation of Sushrutam Samhita based on the original Sanskrit text, 3. Chowkhamba Sanskrit Series office, Varanasi, India: 1991, pp. 213-219.

20. Kar A, Choudhary BK, Bandyopadhyay NG. Comparative evaluation of hypoglycaemic activity of some Indian medicinal plants in alloxan diabetic rats. J Ethnopharmacol. 2003; 84(1):105 8. doi: 10.1016/s0378-8741(02)00144-7.

21. Park A. Park's textbook of social and preventive medicine. Jabalpur (India): Banarasidas Bhanot publishers; 2007, pp. 294298.

22. W.H.O Publication, 1994. Prevention of Diabetes Mellitus: Report of a WHO study group. Technical Report Series No.844, world Health Organization, Geneva, Switzerland, PP. 78. Available on internet at: https://apps.who.int/iris/bitstream/handle/10665/ 39374/WHO TRS 844.pdf?sequence=1\&isAllowed=y

23. Ali L, Khan $\bar{A} K$, Mamun MI, Mosihuzzaman M, Nahar N, Nur-eAlam M, Rokeya B. Studies on hypoglycemic effects of fruit pulp, seed, and whole plant of Momordica charantia on normal and diabetic model rats. Planta Med. 1993; 59(5):408-12. doi: 10.1055/s-2006-959720.

24. Gray AM, Abdel-Wahab YH, Flatt PR. The traditional plant treatment, Sambucus nigra (elder), exhibits insulin-like and insulin-releasing actions in vitro. J Nutr. 2000; 130(1):15-20. doi: 10.1093/jn/130.1.15.

25. Kamanyi A, Djamen D, NKeh, B. Hypoglycemic properties of the aqueous root extracts of Morinda lucida (Rubiaceae) study in the mouse. Phytother Res. 1994; 8(6): 369-371. https://doi.org/10.1002/ptr.2650080612

26. Francis JA, Jayaprakasam B, Olson Lk, Nair M. Insulin secretagogues from Moringa oleifera with cyclo-oxygenase enzyme and lipid peroxidation inhibiting activities. Helvitica Chimica Acta. 2004; 87(2): 317-326. https://doi.org/10.1002/hlca.200490029

27. Galleano M, Verstraeten SV, Oteiza PI, Fraga CG. Antioxidant actions of flavonoids: thermodynamic and kinetic analysis. Arch Biochem Biophys. 2010; 501(1):23-30. doi: 10.1016/j.abb.2010.04.005.

28. Cáceres A, Cabrera $\mathrm{O}$, Morales $\mathrm{O}$, Mollinedo $\mathrm{P}$, Mendia $\mathrm{P}$. Pharmacological properties of Moringa oleifera. 1: Preliminary screening for antimicrobial activity. J Ethnopharmacol. 1991; 33(3):213-6. doi: 10.1016/0378-8741(91)90078-r.

29. Mahajan SG, Mali RG, Mehta AA. Protective Effect of Ethanolic Extract of Seeds of Moringa oleifera Lam. Against Inflammation Associated with Development of Arthritis in Rats. J Immunotoxicol. 2007; 4(1):39-47. doi: 10.1080/15476910601115184.

30. Haslam E. Plant Polyphenols - Vegetable Tannins Revisited. In Chemistry and Pharmacology of Natural Products. Cambridge (UK): Cambridge University Press; 1989, p. 165.
31. England JM, Walford DM, Waters DAW. Re-assessment of the Reliability of the Hematocrit. Br J Haematol. 1972; 23(2): 247-256. https://doi.org/10.1111/j.1365-2141.1972.tb03477.x

32. Bentley SA, Ayscue LH, Watson JM, Ross DW. The clinical utility of discriminant functions for the differential diagnosis of microcytic anemias. Blood Cells. 1989; 15(3):575-82; discussion 583-4. URL: https://pubmed.ncbi.nlm.nih.gov/2620101/

33. Atessahin A, Karahan I, Yilmaz S, Ceribasi AO, Princci I. The effect of manganese chloride on gentamicin -induced nephrotoxicity in rats. Pharmacol Res. 2003; 48(6): 637-642. https://doi.org/10.1016/S1043-6618(03)00227-5

34. Martínez-Salgado C, López-Hernández FJ, López-Novoa JM. Glomerular nephrotoxicity of aminoglycosides. Toxicol Appl Pharmacol. 2007; 223(1):86-98. doi: 10.1016/j.taap.2007.05.004. doi: 10.1016/j.taap.2007.05.004.

35. Priyamvada S, Priyadarshini M, Arivarasu NA, Faroog N, Khan S, Khan SA, Khan W, Yusufi ANK. Studies on the protective effect of dietary fish oil on gentamicin -induced nephrotoxicity and oxidative damage in rat kidney. Prostag Leukotr Ess. 2008; 78(6): 369-381. https://doi.org/10.1016/j.plefa.2008.04.008

36. Balakumar P, Rohilla A, Thangathirupathi A. Gentamicin-induced nephrotoxicity: Do we have a promising therapeutic approach to blunt it? Pharmacol Res. 2010; 62(3):179-186. doi: 10.1016/j.phrs.2010.04.004.

37. Verma AR, Vijayakumar M, Mathela CS, Rao CV. In vitro and in vivo antioxidant properties of different fractions of Moringa oleifera leaves. Food Chem Toxicol. 2009; 47(9):2196-201. doi: 10.1016/j.fct.2009.06.005

38. Wongmekiat $\mathrm{O}$, Leelarugrayub $\mathrm{N}$, Thamprasert $\mathrm{K}$. Beneficial effect of shallot (Allium ascalonicum L.) extract on cyclosporine nephrotoxicity in rats. Food Chem Toxicol. 2008; 46(5):1844-50. doi: 10.1016/j.fct.2008.01.029. 